\title{
RESENHA DO LIVRO “A MEMÓRIA DE FUTURO EM TELA: DIÁLOGOS ENTRE O CINEMA E BAKHTIN"
}

\author{
Maria das Graças Martins Miranda ${ }^{1}$ \\ Fábio Marques de Souza ${ }^{2}$
}

DI CAMARGO, Ivo Jr. A memória do futuro em tela: diálogos entre cinema e Bakhtin. São Paulo, Mentes Abertas, 2020, 198 p. Disponível em:

$<$ https://mentesabertas.minhalojanouol.com.br/produto/310190/a-memoria-do-futuro-em-teladialogos-entre-o-cinema-e-bakhtin> Acesso em: 04 ago.2021.

Ivo Di Camargo Júnior instiga os amantes de cinema e os estudiosos de todas as áreas científicas ligadas à linguagem no livro A memória do futuro em tela: diálogos entre cinema e Bakhtin. O autor aborda a linguagem cinematográfica sob a égide dos estudos linguísticos na perspectiva do filósofo russo Mikhail Bakhtin. A obra está dividida em oito capítulos que versam sobre questões como a memória do futuro em um diálogo com a arte cinematográfica. Os filmes de ficção científicas Blade Runner - O caçador de Androides (1982), Filhos da Esperança (2006), Inteligência Artificial (2001) e Idiocracia (2006), são confrontados e correlacionados uns com os outros em diálogos entre passado, presente e futuro.

No primeiro capítulo, Linguagem, História e Bakhtin: diálogos sobre a sétima arte, são destacados, das teorias do filósofo russo Mikhail Bakhtin, assuntos relacionados à linguagem, como dialogia, polifonia, alteridade, gênero e memória de futuro. A resenha do pensamento linguístico do teórico russo dá o tom das análises mais aprofundadas dos estudos das linguagens cinematográficas com os quais nos presenteia Di Camargo, com exemplos sobre o futuro sujo e o futuro limpo para a interpretação crítica e analítica dos filmes.

Ainda no primeiro capítulo, o autor resgata e retrata o surgimento da sétima arte, desde a sua importância, a sua significação até sua "função" como um meio de entretenimento, ferramenta de produção cultural e de grande difusor de conhecimentos gerais. A imagem,

\footnotetext{
${ }^{1}$ Universidade Estadual da Paraíba (UEPB), Campina Grande - Paraíba - Brasil. Bacharel em Comunicação Social e Licencianda em Letras - Espanhol pela Universidade Estadual da Paraíba (UEPB). É membro do Grupo de Estudos "O círculo de Bakhtin em diálogo", cadastrado no CNPq. ORCID < http://orcid.org/0000-0001-56897302>. E-mail: gracamartinsmiranda@gmail.com.

${ }^{2}$ Universidade Estadual da Paraíba (UEPB), Campina Grande - Paraíba - Brasil. Doutor em Educação pela Universidade de São Paulo (USP). Atua como professor no Departamento de Letras e Artes e no Programa de PósGraduação em Formação de Professores da Universidade Estadual da Paraíba (UEPB) e é colaborador no Programa de Pós-graduação em Linguagem e Ensino na Universidade Federal de Campina Grande (UFCG). ORCID < http://orcid.org/0000-0003-4538-3204>. E-mail: fabiohispanista@gmail.com.
} 


\section{Linguagens - Revista de Letras, Artes e Comunicação - ISSN 1981- 9943 \\ Blumenau, v. 15, n. 1, p. 182-187, jan./abr. 2021. \\ DOI: http://dx.doi.org/10.7867/1981-9943.2021v15n1p182-187}

juntamente com a palavra, possibilita diálogos entre filme e público, esclarecendo que os meios de comunicação de massa, em especial os audiovisuais, são de extrema importância para o mundo contemporâneo. Nesse sentido, alguns filmes estabelecem um papel fundamental ao representar a realidade atual ou futura do universo em que vivemos. Em especial, neste capítulo, é apresentada uma abordagem inicial sobre obras literárias e a sua transposição e adaptação para uma obra audiovisual como, por exemplo, as novelas, as minisséries e os filmes, com destaque para produção, introdução e recriação dos textos literários para uma linguagem cinematográfica. O destaque, neste contexto, é a temporalidade e a valorização dos filmes, consequentemente uma interpretação da narrativa imagética de cada indivíduo sobre as artes audiovisuais do mundo contemporâneo.

O segundo capítulo, A linguagem cinematográfica: deslumbramentos e grandes perspectivas, dedica-se à linguagem específica e renovadora dos produtos audiovisuais, em particular os cinematográficos. Esses produtos são organizados, elaborados e entrelaçados aos estudos de Mikhail Bakhtin com a forma linguística inovadora transmitida pelo cinema. $\mathrm{O}$ autor tem como base, em alguns momentos, a interpretação de Robert Stam sobre Bakhtin e a cultura de massa, destacando que as modalidades verbais, "oral e escrita", não são as únicas ferramentas para que sejamos considerados bons leitores, uma vez que as não-verbais utilizam os signos visuais para expressar ideias, pensamentos e significados como os memes e as charges.

As expectativas que esse mundo midiático causa, cria e transmite para o espectador, por meio dos produtos de massa como as peças de teatro e os filmes transmitidos pelos cinemas, trazem para a linguagem a entrada de um mundo estético produzido pelo diretor, que é feito para encantar, entreter, além de transmitir suas ideologias por trás de cada imagem elaborada e planejada para o filme. Essas mensagens são perceptíveis apenas para alguns críticos e analistas presentes nas apreciações visuais de tais gêneros, por meio de mecanismos de interação social do mundo imaginário com o indivíduo que é real.

Ainda no segundo capítulo, são apreciados alguns pensadores e suas ideologias a respeito da sétima arte. O primeiro escritor é Luís Fernando Veríssimo (2003), que trata o cinema como uma arte democrática e rentável, produto cinematográfico da indústria norteamericana que dissemina sua cultura ao mundo. Já para Robert Stam (1992), que tem sua teoria baseada nos estudos o filósofo russo Bakhtin, todas a ideologias e suas manifestações produzem uma simbólica importância e agregam conhecimentos, nem dispensando nem se apropriando de todos os pensamentos, porém exaltando e reconhecendo o poder existente em cada discurso. 


\section{Linguagens - Revista de Letras, Artes e Comunicação - ISSN 1981- 9943 \\ Blumenau, v. 15, n. 1, p. 182-187, jan./abr. 2021. \\ DOI: http://dx.doi.org/10.7867/1981-9943.2021v15n1p182-187}

Destaca-se a força que o cinema norte-americano possui em relação às demais produções mundiais: além da forte influência que seus produtos e estilos de vida têm sobre a sociedade global. Eles são copiados por meio da grande difusão de sua cultura e costumes que são apresentados nas telas cinematográficas. Segundo Stam (1992), o diálogo acontece entre o público e a obra, a obra e o autor, os atores e a obra, a obra e o público e assim por diante. Uma outra teorização sobre o cinema, apresentada por Di Camargo, vem de Sontag (1987) que trata da linguagem do cinema de forma específica, como os filmes do gênero de ficção científica e do cinema francês, relacionando a palavra com a imagem, citando o cinema mudo, legendado e falado, correlacionando com o ambiente, dando origem a todo o diálogo. Com Fiorin (1988), o autor apresenta o cinema como um transmissor de ideologias e sentidos, desde que seu espectador o reconheça como tal. Essa transmissão ocorre por meio do dialogismo entre a obra e seu público. Nesse sentido, a linguagem do cinema pode ser considerada a reprodução do mundo com suas histórias sociais e culturais produzidas por meio dos filmes.

O autor cita Metz (2003) que trata os filmes como textos e unidades de discurso, enquanto discurso significante e Jacques Aumont (1995) que vê a narrativa fílmica como enunciado que se apresenta como discurso, entre um enunciado e o enunciador. No tópico sobre discurso e significados, no terceiro capítulo, Di Camargo enfoca a "entonação expressiva" quanto ao enunciado e às possíveis e às diversas interpretações que possam ser apresentadas de acordo com a voz de quem o lê, em que a voz do discurso expressa um juízo de valor para sua enunciação. Desta forma, o cinema trata a entonação em suas interpretações como causadora de pretensões e sentidos esperados pelos espectadores.

A Linguagem Cinematográfica, teorias do Cinema e as ideias de Bakhtin é o tema do terceiro capítulo. Nele, o autor trata das noções de discurso do enunciado, com a aproximação e especificidades do gênero romanesco e o cinematográfico, propondo uma leitura aprofundada no desenvolvimento linguístico do cinema. O cinema introduz a polifonia, dialogia e alteridade em seu discurso e desta forma seu objetivo é atrair o espectador a participar e envolver-se com todo o enunciado do filme. De acordo com o autor, Bakhtin afirma que o texto-enunciado passa a ganhar um novo estilo, forma, expressão, conceitos e uma nova linguagem, já que o tempo e espaço estão relacionados na narrativa cinematográfica e são responsáveis por atribuir um significado de grande importância na qualidade, construção, objetivo e interpretação do discurso fílmico. Também está contemplada a distinção do gênero primário e secundário apresentado na obra "Estética da criação verbal", que gera uma nova apresentação aos enunciados em seu contexto. A junção desses conceitos consiste em uma transformação que 


\section{Linguagens - Revista de Letras, Artes e Comunicação - ISSN 1981- 9943 \\ Blumenau, v. 15, n. 1, p. 182-187, jan./abr. 2021. \\ DOI: http://dx.doi.org/10.7867/1981-9943.2021v15n1p182-187}

resulta no texto literário adaptado para o cinema, porém, cada um com as suas particularidades. Desta forma, as adaptações geram sempre novas individualidades e diversidades de interpretações e ideias. As diferentes ideologias envolvidas na criação de um filme são responsáveis pelo produto final com a intenção de agradar seu espectador. Em resumo, o dialogismo está presente desde o roteiro, desenvolvimento, elaboração e conclusão do filme, dando continuidade às ideias no público receptor.

No quarto capítulo, Em busca de um futuro já visto, o futuro aparece como uma possível realidade nos filmes. O cinema com filmes de ficção científica faz uma leitura das possibilidades de fatos e uma fonte de assuntos questionáveis sobre o mundo atual e o mundo no futuro. Geralmente, os filmes de ficção científica estão relacionados aos assuntos do passado e do presente, demonstrando que o futuro da humanidade e do planeta são baseados em assuntos atuais, porém, abordam as probabilidades destes imaginários tornarem-se viáveis. Existem vários estudos e tantas inovações acontecendo gradativamente em nossa rotina de vida e, muitos deles, temos a sensação de já termos visto nas telas do cinema, justamente porque em alguns filmes as histórias têm como base fundamental os assuntos relacionados a um futuro próximo, uma projeção de uma possível realidade do mundo.

No quinto capítulo intitulado Os filmes a serem trabalhados: sinopses o autor cita quatro filmes que serão utilizados para explorar, justificar e explicar a correlação entre as teorias de Mikhail Bakhtin e a linguagem cinematográfica, possibilitada por meio dos diálogos e interpretações constituídas entre o filme e seu espectador, tratado pelo autor como enunciado e enunciador. Para isso, foram selecionados os filmes de ficção científica e futuristas como Blade Runner - O caçador de Androides (1982), Filhos da Esperança (2006), Inteligência Artificial (2001) e o filme Idiocracia (2006) por conterem elementos dialógicos, trançando duas ideias de futuro - o limpo e sujo.

$\mathrm{O}$ autor identificou, apontou e relacionou o uso da linguagem no contexto cinematográfico como linguagens verbais ou não verbais, as várias interpretações e análises contidas nos inúmeros tipos de discurso de contexto imaginativos. Enaltece a sétima arte ao tratar dos assuntos do interesse mundial seja passado, presente ou futuro, não só como um meio de entretenimento, mas também como um difusor de discursos. Utilizando-se de questionamentos, estudos, debates para colaborar com as respostas e soluções positivas ou negativas para o um possível futuro considerado sujo ou limpo.

Em Futuro Sujo, Futuro Limpo e Memória De Futuro, o autor introduz os estudos bakhtinianos nos textos cinematográficos por meio da "língua/história", concentrando seus 


\section{Linguagens - Revista de Letras, Artes e Comunicação - ISSN 1981- 9943 \\ Blumenau, v. 15, n. 1, p. 182-187, jan./abr. 2021. \\ DOI: http://dx.doi.org/10.7867/1981-9943.2021v15n1p182-187}

estudos na teoria do Círculo de Bakhtin. Esse círculo afirma que a língua passa por constantes mudanças, tratando a polifonia, o dialogismo e a alteridade na interação de todos os envolvidos no enunciado, com suas diferentes e livres interpretações do contexto no discurso fílmico apresentado e discutido. $\mathrm{O}$ autor relaciona, dentro do contexto cinematográfico, as experiências com base no conhecimento histórico do passado, com o presente e as possíveis consequências para o futuro, sejam essas positivas ou negativas. Para ele, os filmes são um misto de realidade com a ficção científica, numa percepção para um futuro subjetivo e superficial, com especulações baseadas no histórico da humanidade, enxergando esse futuro como esperançoso ou desastroso, seguindo uma ideia de percepção positiva ou negativa do roteirista/diretor do filme, dissolvendo essa comunicação nas variadas interpretações dos espectadores, tratados pelo autor do livro como enunciadores. A ideia é criar esses diálogos, seja para causar polêmica, novas ideias, críticas, observações e discussões: o importante é envolver o espectador com a história.

O sétimo e oitavo capítulos tratam das Visualidade: futuro sujo e Visualidade: futuro limpo, usando os filmes já citados anteriormente como exemplos para apontar tais correlações deste pensamento, concluindo a sua teoria de estudo e ideologias para essa concepção das ideias entre ambos os futuros neste contexto fílmico. Usando da teoria bakhtiniana para que os leitores compreendam essa relação e ideia deste futuro apresentado nas telas dos cinemas, o autor aborda os aspectos do futuro sujo e limpo, introduzindo nos estudos os pensamentos bakhtinianos.

O livro centra-se no contexto cinematográfico e seu produto filme como um meio transmissor e difusor da linguagem, que gera diálogos e discussões. O filme, para Di Camargo, é também percebido como ferramenta de estudo na prática de mudar as ideologias da sociedade e na construção de um mundo melhor. O cinema, assim como os demais meios de comunicação de massa, tem a capacidade de influenciar no desenvolvimento, formação e construção do senso crítico social. Ele é um difusor de ideias e valores culturais que expande conhecimento e informação. O produto cinematográfico também é uma ferramenta para estudos, pois promove conhecimentos, reflexões e discursos em muitas instituições de ensino. Análises como as propostas pelo autor, podem ser instrumentos para professores e demais formadores de opinião ao trabalhar/apresentar filmes aos seus públicos. O cinema é capaz de moldar o senso crítico e analítico das pessoas, agindo sobre os mais variados assuntos de nossa sociedade, em que muitos filmes influenciam a mudança de comportamento e pensamento sobre nossa realidade e nosso futuro. 
O autor cursou estágio de pós-doutorado no Programa de Pós-Graduação em Formação de Professores da Universidade Estadual da Paraíba (UEPB). É mestre e doutor em Linguística e, atualmente, doutorando em Educação pela Universidade Federal de São Carlos (UFSCar). Di Camargo desenvolve pesquisas em linguagem cinematográfica, Mikhail Bakhtin e educação e é formador de Língua Portuguesa no Centro Educacional Paulo Freire da Prefeitura Municipal de Ribeirão Preto - São Paulo.

\section{REFERÊNCIAS}

AUMONT, J. et ali. A estética do filme. Campinas: Papirus, 1995.

FIORIN, J. L. Linguagem e ideologia. São Paulo: Ática, 1988.

METZ, C. Linguagem e cinema. São Paulo: Perspectiva, 2004.

SONTAG, S. Contra a interpretação. Porto Alegre: L \& PM, 1987.

STAM, R. Bakhtin, da teoria literária à cultura de massa. São Paulo: Ática, 1992.

VERÍSSIMO, L.F. Banquete com os Deuses: Cinema. Literatura, Música e Outras Artes. São Paulo: Objetiva, 2003. 